\title{
PHYTOCHEMICAL SCREENING AND ANTIMICROBIAL ACTIVITY OF BLUMEA MOLLIS (D.DON) MERRILL
}

\section{JYOTHILEKSHMY V, ANJALI NAIR G, VYSHAK K, RADHIKA R NAIR, AMRITA MURALIKRISHNAN, JIFITHA BANU, LEENA K PAPPACHEN*}

Department of Pharmaceutical Chemistry and Analysis, Amrita School of Pharmacy, Amrita Vishwa Vidyapeetham, AIMS Health Sciences Campus, Kochi, Kerala, India. Email: leenakpappachen@aims.amrita.edu

Received: 14 July 2018, Revised and Accepted: 03 October 2018

ABSTRACT

Objective: The objective of this research was to carry out the preliminary phytochemical screening and to evaluate the antimicrobial activity of the methanolic extract of the Blumea mollis.

Methods: In the present work, the phytochemicals of the whole plant were extracted using petroleum ether, chloroform, methanol, ethanol, and distilled water. These were then screened for triterpenes/steroids, alkaloids, anthraquinones, coumarins, flavonoids, saponins, tannins, and phenolic acids using standard methods. Further, the antimicrobial activity of the methanolic extract was determined using Gram-positive and negative bacteria. Agar well diffusion method was employed for antimicrobial activity study, and the zone of inhibition was found out.

Results: The intensity of the color produced or the precipitate formed was used as the analytical response to these tests. Flavonoids, tannins, and phenolic acids showed positive results for phytochemical screening. The concentration of total phenols and flavonoids of the decoction was $45.5 \pm 0.2000 \mu \mathrm{g} / \mathrm{ml}$ gallic acid equivalent and $42.3 \pm 0.3606 \mu \mathrm{g} / \mathrm{ml}$ quercetin equivalent, respectively. Staphylococcus aureus, Escherichia coli, and Candida albicans were inhibited by the methanolic extract of $B$. mollis in agar well diffusion test.

Conclusion: The results of the present study showed that the methanolic extract of $B$. mollis contains glycosides, phenolics, tannins, and flavonoids. Plant possesses significant antibacterial and antifungal property; the potent antimicrobial activity of the plant could be attributed to the presence of flavonoids and phenolic compounds in it.

Keywords: Antimicrobial, Compositae, Phenolic, Flavonoid.

(C) 2019 The Authors. Published by Innovare Academic Sciences Pvt Ltd. This is an open access article under the CC BY license (http://creativecommons. org/licenses/by/4. 0/) DOI: http://dx.doi.org/10.22159/ajpcr.2019.v12i2.28477

\section{INTRODUCTION}

Ayurveda is the one of the major systems of alternative and complementary medicine. Various drug formulations are employed in Ayurvedic system of medicine. Apart from other herbal systems, greater parts of its medicaments are based on indigenous herbals. A thorough and fractionate knowledge about the medicinal plant is mandatory for all who are working in the field of Ayurveda to identify and select the appropriate plant for a specific disease [1]. In the recent years, the interest in medicinal plants has increased across a great deal and the people from the West have also taken this matter seriously by conducting various researches on plant-based medicines [2]. The World Health Organization (WHO) currently encourages, recommends, and promotes traditional remedies in the National Health-care Programs as they are easily available at low cost comparatively safe and are culturally acceptable. Further, the WHO estimates that about three-quarters of the world's population currently use herbs and other forms of traditional medicines to treat the ailments [3]. Plant-based medicines are safe as they have fewer side effects [4]. However, one of the limitations in the acceptance of Ayurvedic medicines is the lack of standard quality control profiles. The profile of constituents in the final product has implication in its efficacy and safety [5].

Blumea mollis (D.Don) Merrill, popularly known as the Soft Blumea, is a pleasant aromatic annual herb and commonly found in the plains of India, outer Himalaya, Sri Lanka, and Myanmar [6]. It is an erect, aromatic, densely viscid, annual herb or undershrub with leaves ovateoblong, serrate. It bears rose to pink flowers which are borne in dense flat-topped clusters. Flower heads are bell shaped. Florets are bisexual. They are found as weed in wastelands and in agricultural lands.
The juice of the leaves is given to relieve headache. The plant extract also possesses significant anti-inflammatory properties. The juice of the plant has astringent, diuretic, febrifuge, and anthelmintic properties. Infectious diseases are the transmissible diseases caused by infection of microorganisms. They are the major cause of death in the world [7]. The plant contains a comparable amount of chemical constituents such as sabinene, $\gamma$-terpinene, linalool, estragole, copaene, $\beta$-caryophyllene, and viridiflorene [8]. Recent studies on the plant have been focused on its antioxidant activity which is its ability to protect the body, cells, and tissues from continuously threatened by the damage caused by free radicals and reactive oxygen species which are produced during normal oxygen metabolism due to the increased content of phenols, flavonoids, and other constituents [9]. Other medicinal uses of the plant, specifically its antipyretic and anti-inflammatory properties, have also been reported [10]. The aim of this research was to perform phytochemical and antimicrobial activities on the crude extract of $B$. mollis.

\section{METHODS}

\section{Collection of the plant}

Leaves of the plant B. mollis (Family: Apocynaceae) were collected from the wastelands of Kollam district of Kerala, India. The plant material collected was taxonomically identified by Botanist, Botany Department, Sacred Heart College, Thevara. A voucher specimen has been preserved in our laboratory for future reference.

Plant material - Standardization

Based on the methods specified in Indian Pharmacopoeia, plant material was powdered and ash values (total ash, acid insoluble ash, and water soluble ash) were determined [11]. 
Total ash

Weighed and ignited the flat, thin, silica crucible. Accurately weighed about $2 \mathrm{~g}$ of the powdered drug into the dish. Heated using a burner, with a flame of about $2 \mathrm{~cm}$ height, and the dish was supported about $7 \mathrm{~cm}$ above the flame. Heating was continued until the vapors almost ceased to be evolved, then lowered the dish, and heated more strongly until all the carbon had burnt off. Cooled in a desiccator. The procedure was repeated until a constant weight was obtained. With reference to the air-dried sample of the crude drug, the percentage of total ash was calculated.

\section{Water-soluble ash}

In a silica crucible, the total ash was taken. To this, $25 \mathrm{ml}$ of water was added. Boiled for $5 \mathrm{~min}$. In a Whatman filter paper, insoluble matter was collected. It was washed with hot water. In a silica crucible, it was ignited (15 min). The weight of this ash was calculated by subtracting it from the weight of the total ash. The percentage of water-soluble ash was calculated in mg per gram of air-dried material. The average was calculated by repeating the experiment and is noted in Table 1.

\section{Acid-insoluble ash}

In a silica crucible, total ash was taken. To this, $25 \mathrm{ml}$ of hydrochloric acid was added and boiled for 5 min. In a Whatmann filter paper, the insoluble matter was collected. It was washed with hot water. In a silica crucible, it was ignited (30 min). The weight of this ash was calculated by subtracting it from the weight of the total ash. The percentage of acid-insoluble ash was calculated in mg per $g$ of the air-dried material. The average was calculated by repeating the experiment thrice and is noted in Table 1.

\section{Extraction of plant material}

The extractive value was found out by simple maceration process [12]. $50 \mathrm{~g}$ of the powdered leaves of B. mollis was macerated with $250 \mathrm{ml}$ petroleum ether in a $500 \mathrm{ml}$ round bottom flask. The mixture was shaken continuously for $30 \mathrm{~min}$ and occasionally for $6 \mathrm{~h}$. After about $18 \mathrm{~h}$, the petroleum ether was separated by filtration and the marc was evaporated to dryness. Collected the residue and calculated the percentage of extractive. Using various solvents (chloroform, methanol, ethanol, and distilled water), the procedure was repeated.

\section{Organoleptic and phytochemical evaluation of extracts}

The extract was characterized for various organoleptic characters such as color, odor, and taste. For determining the phytochemical constituents, tests for carbohydrates, alkaloids, proteins, glycosides, phenols, tannins, flavonoids, triterpenoids, saponins, gums, and mucilages were carried out $[13,14]$.

\section{Estimation of total phenolic content}

About $250 \mu$ l of Folin-Ciocalteu reagent (1N) was transferred to $500 \mathrm{ml}$ decoction at three different concentrations, i.e., 25, 50, and $100 \mu \mathrm{g} / \mathrm{ml}$. At room temperature, the mixture was allowed to stand for $2 \mathrm{~min}$. 10\% of $1.25 \mathrm{ml}$ solution of sodium carbonate was added and incubated at room temperature (45 $\mathrm{min})$. With gallic acid as the reference, the

\section{Table 1: Ash value of $B$. mollis}

\begin{tabular}{ll}
\hline$\%$ w/w of total ash value & $2.36 \pm 0.07071$ \\
$\%$ w/w of water-soluble ash & $2.135 \pm 0.0070$ \\
$\%$ w/w of acid-soluble ash & $1.15 \pm 0.0282$ \\
\hline B. mollis: Blumea mollis & \\
\multicolumn{2}{c}{ Table 2: Extractive value of $B$. mollis by simple maceration } \\
\hline \% w/w of petroleum ether & $3.13 \pm 0.01732$ \\
$\%$ w/w of chloroform & $4.22 \pm 0.1002$ \\
$\%$ w/w of methanol & $9.35 \pm 0.1253$ \\
$\%$ w/w of ethanol & $11.32 \pm 0.1115$ \\
\hline
\end{tabular}

*Values are expressed in mean \pm SD. B. mollis: Blumea mollis. SD: Standard deviation absorbance of the resulting solution was measured $(760 \mathrm{~nm})$. To determine the phenolic content of the decotion, a calibration graph was plotted. Phenolic content of samples (test) was expressed as w/w \% gallic acid equivalent [15].

\section{Estimation of flavonoid content}

Using colorimetric method as described by Zhischen et al. [16], the flavonoid content was determined. $100 \mathrm{ml}$ of each sample was diluted with distilled water. $5 \%$ of $30 \mu \mathrm{l}$ of sodium nitrite was added. At $510 \mathrm{~nm}$, the absorbance was recorded. To determine flavanoid content, quercetin was used as standard. A calibration graph was plotted, and the values were expressed as $\mathrm{w} / \mathrm{w} \%$ quercetin equivalents. The analysis was performed in triplicates.

\section{Antimicrobial studies of plant extract}

By observing growth response of various microbes to those plant tissues which are placed in contact with them, the antimicrobial activity of the plant can be assessed. To detect the antimicrobial activity of the plant extracts, three conditions must be fulfilled. First, the plant extract must be brought into contact with the cell wall of the microorganism that has been selected for the test. Second, the conditions must be adjusted so that the microorganisms would not grow, when no antimicrobial agents are present. Third, there must be some means of judging the amount of growth, if any $[17,18]$

\section{Media and Chemicals}

The media and chemicals such as nutrient broth (NB), nutrient agar (NA), Sabouraud Dextrose Agar (SDA), Sabouraud Dextrose Broth (SDB), peptone water and antibiotics-Chloramphenicol (bacteria), and Candid-B (fungus) were procured from Hi-Media Laboratories (Mumbai, India). Dimethyl sulfoxide was procured from E. Merck Ltd. (Mumbai, India).

\section{Microorganisms used}

The microbial cultures were Escherichia coli, Staphylococcus aureus, and Candida albicans procured from the National Center for Industrial Microorganisms (Pune, India).

\section{Preparation and Standardization of Stock cultures}

Cultures on the receipt were subcultured in NA plates and further stored in slants as stock cultures. For the experiments, stock culture was prepared by inoculating each culture from the slants to flask in sterile NB and incubated at $37^{\circ} \mathrm{C}$ for $24 \mathrm{~h}$. The stock culture was adjusted to 0.5 McFarland standard turbidity and used for assay, in case of fungus SDA and SDB were used instead of NA and NB.

\section{Procedure}

Inoculum $(0.1 \mathrm{ml})$ from a standardized culture of the test organism was spread uniformly on prepared sterile NA plates. Using a sterile borer, wells were prepared (diameter $10 \mathrm{~mm}$ ) and $100 \mu \mathrm{l}$ of test substance and the standard antibiotics were added in each well separately. The standard antibiotic, chloramphenicol was tested against bacteria and candid-B ointment against fungus. For diffusion of test solutions into the medium, the plates were placed at $4^{\circ} \mathrm{C}$ for $1 \mathrm{~h}$. These plates were incubated at an optimal temperature and for a sufficient period of time $\left(24 \mathrm{~h}\right.$ at $\left.37^{\circ} \mathrm{C}\right)$ for the growth of at least $10-15$ generations. The microbial growth was determined by measuring the zone of inhibition around the well in $\mathrm{mm}[19,20]$.

\section{Statistical analysis}

The results were expressed as mean \pm standard deviation. At least three individual experiments should be carried, unless otherwise specified.

\section{RESULTS AND DISCUSSION}

Standardization of plant material (Tables 1 and 2)

Different ash values of $B$. mollis were performed, and the results obtained were used for standardization and identification. Extractive values were performed by simple maceration method. Simple ethanolic maceration of B. mollis yielded maximum extractive value $(11.32 \pm 0.1115 \% \mathrm{w} / \mathrm{w})$. 
Table 3: Phytochemical screening of Blumea mollis

\begin{tabular}{|c|c|c|c|c|c|c|c|c|c|c|}
\hline \multirow[t]{2}{*}{ Chemical test } & \multicolumn{2}{|c|}{ Pet ether } & \multicolumn{2}{|c|}{ Chloroform } & \multicolumn{2}{|c|}{ Methanol } & \multicolumn{2}{|l|}{ Ethanol } & \multicolumn{2}{|c|}{ Aqueous } \\
\hline & Leaves & Stem root & Leaves & Stem root & Leaves & Stem root & Leaves & Stem root & Leaves & Stem root \\
\hline Carbohydrates & - & + & - & - & + & + & + & - & + & + \\
\hline Proteins & - & - & - & - & - & - & - & - & - & - \\
\hline Fats and oils & - & - & - & - & - & - & - & - & - & - \\
\hline Glycosides & + & - & + & + & + & - & + & - & + & + \\
\hline Tannins & - & + & + & + & + & + & + & + & + & + \\
\hline Phenols & - & - & - & - & + & + & + & + & + & - \\
\hline Saponins & - & - & - & - & - & - & - & - & - & - \\
\hline Flavonoids & - & - & - & - & + & - & + & + & - & - \\
\hline Gums and mucilage & - & - & - & - & - & - & - & - & - & - \\
\hline
\end{tabular}

+: Present, - Absent. B. mollis: Blumea mollis

Table 4: Zone of inhibition of the methanolic extract of $B$. mollis

\begin{tabular}{|c|c|c|c|c|c|}
\hline \multirow[t]{2}{*}{ Extract used } & \multirow[t]{2}{*}{ Organism } & \multirow[t]{2}{*}{ Standard } & \multirow[t]{2}{*}{ Sensitivity } & \multicolumn{2}{|c|}{ Zone of inhibition $(\mathrm{cm})$} \\
\hline & & & & Standard & Extract \\
\hline \multirow[t]{3}{*}{ Methanolic extract of $B$. mollis } & E. coli & Chloramphenicol & + & 5.5 & 3.7 \\
\hline & S. aureus & Chloramphenicol & + & 5.1 & 2.7 \\
\hline & C. albicans & Candid-B & + & 1.9 & 1.3 \\
\hline
\end{tabular}

E. coli: Escherichia coli, S. aureus: Staphylococci aureus, C. albicans: Candida albicans, B. mollis: Blumea mollis

Organoleptic characters revealed a dark grayish green color, tasteless, and characteristic odour.

\section{Phytochemical screening (Table 3)}

Phytochemical screening showed the presence of carbohydrates, tannins, flavonoids, and phenolics. The presence of carbohydrates was estimated by carrying out Molisch's test, Benedict's test, Barfoed's test, and Fehling's test. Flavonoids were verified for the studied chloroform, ethyl acetate, and residual ethanol fractions on treatment with the Shinoda reagent, boric acid/oxalic acid solution, and zinc/hydrochloric acid reaction. The flavonoid content has been widely investigated in B. mollis. A $2.5 \%$ gelatin aqueous solution, a $1 \%$ ferric chloride aqueous solution, and a $5 \%$ ferric ammonium sulfate in $\mathrm{HCl}(2 \mathrm{~mol} / \mathrm{L})$ yielded positive results for tannins in the residual ethanol fraction from the crude extract.

\section{Total phenolic and flavonoid content}

The total phenolic and flavonoid content of $B$. mollis was found to be $45.5 \pm 0.2000 \mu \mathrm{g} / \mathrm{ml}$ gallic acid equivalent and $42.3 \pm 0.3606 \mu \mathrm{g} / \mathrm{ml}$ quercetin equivalent.

\section{Antimicrobial studies (Table 4)}

Antimicrobial studies were performed and the zone of inhibition was found out. The extract showed positive sensitivity toward all the organisms. The compounds responsible for this activity were not isolated. However, the preliminary phytochemical analysis indicated the presence of flavonoids, carbohydrates, phenols, and tannins. The activity might be due to the individual or combined action of the abovementioned constituents.

\section{CONCLUSION}

Based on the present investigation, a growth inhibiting compound of methanol extract $B$. mollis was identified which inhibits the growth of bacteria and fungi. The phytochemical screening showed the presence of several bioactive compounds of great economic potentialities. The present study ensures further detailed investigations which necessitate the isolation, purification, and structural elucidation of active chemical constituents.

\section{ACKNOWLEDGMENT}

We express our sincere gratitude to Amrita School of Pharmacy, Kochi, for providing the facilities for the successful completion of our work.

\section{AUTHORS' CONTRIBUTIONS}

Conception and design of the work were done by Dr. Leena K Pappachen. Extraction, phytochemical screening, and pharmacological evaluation were done by Jyothilekshmy, Anjali Nair, and Vyshak. Interpretation of data and drafting of the article were done by Radhika R Nair, Amrita Muralikrishnan, and Jiffitha Banu.

\section{CONFLICTS OF INTEREST}

The authors declare that there are no conflicts of interest.

\section{REFERENCES}

1. Ballabh B, Chaurasia OP. Traditional medicinal plants of cold desert Ladakh - Used in treatment of cold, cough and fever. J Ethnopharm 2007:112:341-9.

2. Perumal SR, Ignacimuthu S. Screening of 34 Indian medicinal plants for antibacterial properties. J Ethnopharm 1998;62:173-8.

3. Leena KP, Sreelakshmi KS. Phytochemical screening and In vitro cytotoxicity studies of Mussaenda frondosa Linn leaves. Res J Pharm Tech 2017;10:4227-30.

4. Sreesha NN, Alexeyena V, Meenu B, Greeshma R, Neeraja ED. Comparative evaluation of Coriandrum sativum Linn. And Apius graveolens for antimicrobial activity. Res J Pharm Technol 2017;10:541-4.

5. Shaikh S, Jain V. Development and validation of RP-HPLC method for the simultaneous determination of curcumin, piperine and camphor in an ayurvedic formulation. Int J Pharm Pharm Sci 2018;10:115-21.

6. Chopra RN, Nayer SL, Chopra IC. Glossary of Indian Medicinal Plants. New Delhi: Publications and Information Directorate; 1992.

7. Varghese E, Pappachen KL, Narayanan SS. Isolation and evaluation of antimicrobial properties of isolated phytoconstituents of fruits of Helicteres isora Linn. Res J Pharm Biol Chem Sci 2012;3:959-64.

8. Senthilkumar A, Kannathasan K, Venkatesalu V. Antibacterial activity of the leaf essential oil of Blumea mollis (D. Don) Merr. World J Microbiol Biotechnol 2009;25:1297-1300.

9. Figueroa LA, Navarro LB, Vera MP, Petricevich VL. Antioxidant activity, total phenolic content and flavanoid content and cytotoxicity evaluation of Bougainvillea xbuttiana. Int J Pharm Pharm Sci 2014;6:497-502

10. Senthilkumar A, Kannathasan K, Venkatesalu V. Chemical constituents and larvicidal property of the essential oil of Blumea mollis (D. Don) Merr. Against Culex quinquefasciatus. Parasitol Res 2008;103:959-62.

11. Devi GB, Amutha K. Anti-Inflammatory and anti-pyretic activities of Blumea mollis (D. Don) Merr. Res Rev J Pharm Phytochem 2011;3:14-6. 
12. India, Ministry of Health and Family Welfare. Indian Pharmacopoeia. New Delhi, India: Ministry of Health and Family Welfare; 1996.

13. Kokate CK. Practical Pharmacognosy. $1^{\text {st }}$ ed. New Delhi: Vallabh Prakashan; 1986

14. Kandelwall KR. Practical Pharmacognosy Techniques and Experiments. $9^{\text {th }}$ ed. Pune: Nirali Prakashan; 2002.

15. Makkar HP, Bluemmel M, Borowy NK, Becker K. Gravimetric determination of tannins and their correlations with chemical and protein precipitation methods. J Sci Food Agric 1993;61:161-5.

16. Zhishen J, Mengcheng T, Jianming W. The determination of flavonoids contents in mulberry and their scavenging effects on superoxide radicals. Food Chem 1999;64:555-9.

17. Parthasarathy R, Ilavarasan R, Nandanwar R. A study on preliminary phytochemical and diuretic activity of bark of Thespesia populnea. Int J Pharm Sci Res 2010;1:72-7.

18. Arora DS, Kaur J. Antimicrobial activity of spices. Int J Antimicrob Agents 1999;12:257-62.

19. Kim J, Marshall MR, Wie C. Antibacterial activity of some essential oil components against five food borne pathogens. J Agric Food Cem 1995;43:2839-45

20. Mothana RAA, Lindequist U. Antimicrobial activity of some medicinal plants of the Island Soqotra. J Ethno Pharm 2005;96:177-81. 